\title{
Design and Evaluation of Software Tool for Optimal Design of Sprinkler Irrigation System
}

\author{
P.R. Landge*, M. Kothari, S.R. Bhakar, P.R. Patil and M.A. Patil \\ Department of Soil and Water Engineering, College of Technology and Engineering, \\ Maharana Pratap University of Agriculture and Technology, \\ Udaipur (Rajasthan) 313001, India \\ *Corresponding author
}

\begin{abstract}
A B S T R A C T
Improving both the efficiency of water uses and water productivity in irrigation require appropriate solutions for design, management and maintenance of irrigation systems. Various software tools proved useful for designing new systems and to improve

Keywords

Design, Sprinkler irrigation system, $\mathrm{C}$ language, Cost economics

\section{Article Info}

Accepted:

24 January 2018

Available Online:

10 February 2018 functioning and management of systems under operation. In this complex context, it is important that farmers could rely on instruments and practices that enable a better management of water at the field scale, whatever the irrigation method they adopt. Development of software tool aimed to design and perform cost economics analysis of sprinkler irrigation system. Algorithm prepared according to the actual design of the sprinkler irrigation system and then the interface was prepared in Visual Basic Studio 2008 $\mathrm{C}$ language. The step by step procedure followed in the design of the sprinkler irrigation system by providing different screens with the design of different accessories on along. Initially software tool calculates the crop water requirement for the crops included in database as the CROPWAT is linked with it. Furthermore, the selection of sprinkler, lateral, submain and main in terms of diameter and length done on the basis of permissible head loss. Provided simple informative bullets and tabs are easy to understand to perform the operation. Software allows user to alternate the values at distant stages besides database on the basis of field conditions that ultimately increase practical applicability of the tool. The software tool minimizes the time required for design and also quotation for the survey.
\end{abstract}

\section{Introduction}

In the global scenario, the demand for water has been on the rise from all water user sectors. Agriculture is one of the most water demanding and consuming user sector in India and worldwide. India is blessed with abundant water resources, however, due to various physiographic constraints, existing legal constraints and the present method of utilization, the utilizable water for irrigation is very limited. Further, the misuse of water leads to water logging and salt problems when considered with the utilization for agriculture. In India, the irrigated area consists of about 36 percent of the net sown area. Presently, the agriculture sector accounts for about 83 per cent of all water uses. 
In the sprinkler method of irrigation, water is sprayed into the air and allowed to fall on the ground surface somewhat resembling rainfall. The spray is developed by the flow of water under pressure through small orifices or nozzles. The pressure is usually obtained by pumping. With careful selection of nozzle sizes, operating pressure and sprinkler spacing the amount of irrigation water required to refill the crop root zone can be applied nearly uniform at the rate to suit the infiltration rate of soil.

Virtually, all computer-based decision support systems for irrigation management developed during the past forty years have evolved from the ground breaking work of Jensen and others in the late 1960's (Jensen, 1969; Jensen et al., 1970). There have been wide variations in detail and format, but not in the underlying management paradigm. Essentially, all such programs have been designed for conventional irrigation, i.e. irrigation to meet crop water demands in order to avoid crop stress that would reduce yields or quality.

Farmers with small land holdings cannot afford an engineer to design a Micro-irrigation system for their fields and poorly designed and installed systems leads to poor efficiency. There is much software available for Microirrigation system design. Virtually, all computer-based decision support systems for irrigation management developed during the past forty years. There are few commercial software tools available for design, but these cannot be afforded by small farmers.

\section{Materials and Methods}

The present study deals with the objectives to develop user friendly software for optimal design of sprinkler irrigation system. A stepby-step checklist of the procedure normally used in planning a sprinkler irrigation system follows design and selection of lateral, submain and mainline that can yield the minimum total cost for a predetermined annual period of operation and fulfil the hydraulics of the sprinkler irrigation system.

\section{Design of sprinkler irrigation system}

Proper design of sprinkler irrigation system for the individual field is very important for successful execution of the design of sprinkler irrigation system. The following assumptions are made in development of software for design of sprinkler irrigation system.

The fields are of regular shape, viz. square or rectangle

The land slope generally varies from 0.05 to 0.20 per cent in heavy soils and 0.25 to 0.65 per cent in light soil. Hence, in this study the fields are considered to be fairly leveled in topography.

If field having some slope along length or width then user need to specify it on design of lateral window of developed software in percent.

The fields have no hindrances for laying of submain / lateral.

The outlet valves are required to connect the field mains with the network main line. A valve with single outlet permits irrigation in one direction where as a valve with two outlets permit irrigation in two different directions. Such valve is supposed to be located at the midpoint of a short dimension of the field boundary.

The main line is laid along the length of field only and they do not cross the fields. The selection of emitter is based on crop water requirement per cent wetted area of that crop and the soil type. The soil is considered homogenous for a field. 
The size of lateral / submain / main is to be selected from the available range of the pipes.

The design procedure for the design of the sprinkler irrigation system is discussed in this section.

\section{Irrigation requirement}

The irrigation requirement is the amount of water that must be applied to meet crop needs in its life cycle. For a particular irrigation period, it is a sum of daily irrigation required during the irrigation period. The required timing and amount of applied water is to be determined by the prevailing climatic conditions, the crop and its stage of growth, soil properties (such as water holding capacity), and the extent of root development. Water within the crop root zone is prevailed to be the source of water for crop evapotranspiration. Thus, it is important to consider the reference crop evapotranspiration and crop coefficient to determine the irrigation water requirements.

\section{Reference crop evapotranspiration}

Evapotranspiration is a complex phenomenon and depends on several Climatological factors, such as temperature, humidity, wind speed, radiation, and type and growth stage of crop. In this study, the average daily reference evapotranspiration for 32 years (1985-2016) estimated using CROPWAT software.

\section{Crop coefficient}

The crop coefficient, $K_{c}$, is basically the ratio of the crop $\mathrm{ET}_{\mathrm{c}}$ to the reference $\mathrm{ET}_{\mathrm{o}}$, and it represents an integration of the effects of primary characteristics like, crop height, albedo, canopy resistance and evaporation from soil especially exposed soil. In the crop coefficient approach the crop evapotranspiration, $\mathrm{ET}_{\mathrm{c}}$, is calculated by multiplying the reference crop evapotranspiration, $\mathrm{ET}_{\mathrm{o}}$, by a crop coefficient, Kc.

The FAO 56 provides the guidelines for the crop coefficient and stage wise values of the crops are selected for the estimation of crop evapotranspiration. Figure 1 shows a typical graphical representation of $\mathrm{K}_{\mathrm{c}}$ values for different plant growth stages.

\section{Crop evapotranspiration}

The daily crop evapotranspiration (ETc) estimated from the equation 3.1

$E T_{c}=E T_{r} \times K_{c} \quad \stackrel{\cdots}{(3.1)}$

Where,

ETc = Daily maximum crop evapotranspiration, $\mathrm{mm}$

$\mathrm{ETr}=$ Daily reference crop evapotranspiration, $\mathrm{mm}$

$\mathrm{Kc}=$ Daily crop coefficient

\section{Crop water requirement}

The daily water requirement is estimated with formula given in equation 3.2

$\mathrm{WR}=\operatorname{ETc} \times \mathrm{Wa} \quad \stackrel{(3.2)}{ }$

Where,

$\mathrm{WR}=$ Daily water requirement, $\mathrm{mm}$

ETc = Daily maximum crop evapotranspiration, $\mathrm{mm}$

$\mathrm{Wa}=$ Wetted area as the percentage of the total area, fraction 
The irrigation requirement is estimated with the formula given in equation 3.3

$\mathrm{IR}=\mathrm{WR} / \mathrm{Eff} \quad \stackrel{\ldots}{(3.3)}$

Where,

$\mathrm{IR}=$ Daily irrigation requirement, $\mathrm{mm}$

$\mathrm{WR}=$ Daily water requirement, $\mathrm{mm}$

$\mathrm{E}_{\mathrm{ff}}=$ Distribution uniformity of the sprinkler irrigation system, fraction

\section{Sprinkler discharge}

Sprinkler discharge of each sprinkler is depends upon sprinkler spacing and the water application rate and can be compound with equation 3.4 .

$\mathrm{q}=\frac{S_{1} \times S_{m} \times I}{3600} \quad \ldots$

Where,

$\mathrm{q}=$ Discharge of individual sprinkler lit/sec

$\mathrm{S}_{1}=$ Sprinkler spacing along the lateral, $\mathrm{m}$

$\mathrm{S}_{\mathrm{m}}=$ Lateral spacing along the main, $\mathrm{m}$

$I=$ Optimum application rate, $\mathrm{mm} / \mathrm{hr}$

\section{Irrigation time}

The time of operation will be calculated by this equation

$T=\frac{I R \times A}{q e \times N p} \quad \ldots$

Where,

$\mathrm{A}=$ Field area, $\mathrm{m}^{2}$

$\mathrm{q}_{\mathrm{e}}=$ Average discharge of sprinkler, $1 / \mathrm{hr}$
The minimum possible number of subunit can be decided with the formula given in equation 3.6.

$\mathrm{Ts}=\frac{\mathrm{T}}{\mathrm{Top}} \quad \stackrel{ }{(3.6)}$

Where,

$\mathrm{T}=$ Possible hours available for irrigation in a day, hrs

$\mathrm{T}_{\mathrm{op}}=$ Time of operation, $\mathrm{hr}$

\section{Design of lateral, submain and mainline}

In designing of lateral and submain for an individual field, the selection of a pipe diameter selected to satisfy the design head loss criteria and pressure requirement along the length of run.

\section{Design of laterals}

In sprinkler irrigation design, frictional head loss in particular pipe type can restrict the selection of size of it, therefore, laterals are designed to maintain the emitter discharge variation along with the length of it, in an acceptable range. The main cause of the variation in the discharge of emitter along the lateral is the loss of pressure due to friction. The most commonly adopted equation for estimating the head loss in a lateral pipe is a Hazen-William equation given in equation (3.7)

$l_{l}=1.212 \times 10^{10} \times\left(Q_{l} / C\right)^{1.852}\left(D_{l}\right)^{-4.871} \times L_{l} \times F_{l}$

Where,

$\mathrm{J}_{1}=$ Head loss due to friction, $\mathrm{m}$

$\mathrm{Q}_{1}=$ Lateral flow rate, $\mathrm{lph}$ 
$\mathrm{Q}_{1}=\left(\mathrm{q}_{\mathrm{e}} \times \mathrm{n}_{\mathrm{e}}\right) / 3600$

$\mathrm{q}_{\mathrm{e}}=$ Average emitter discharge, lph

$\mathrm{n}_{\mathrm{e}}=$ Number of emitters along lateral

$\mathrm{C}=$ Pipe friction coefficient, 140 for LDPE material

$\mathrm{D}_{1}=$ Inside diameter of lateral pipe, $\mathrm{mm}$

$\mathrm{L}_{1}=$ Length of lateral, $\mathrm{m}$

$F_{1}=$ Reduction coefficient for lateral, dimensionless

$\mathrm{F}_{\mathrm{l}}=\frac{\sum_{\mathrm{i=1}}^{\mathrm{ne}} \mathrm{1}^{1.85}}{n \mathrm{e}^{2.85}} \cdots$

Where,

$\mathrm{J}_{1}=$ Head loss due to friction, $\mathrm{m}$

$\mathrm{L}_{1}=$ Length of lateral, $\mathrm{m}$

Maximum permissible head loss along a lateral is considered in the selection of lateral size. The diameter of lateral is usually selected such that the difference in the discharge between two extreme emitters operating simultaneously should not exceed 10 per cent.

For having 10 per cent variation in flow, the pressure head difference between emitter should not exceed 10 to 15 per cent of average operating head, where long path emitters are used and 20 per cent for turbulent flow emitters. The maximum difference in pressure due to head loss occurs between the control point at the inlet and the last emitter of the last lateral. The allowable friction head loss along the lateral is estimated using equation (3.9).

$$
\Delta H l=0.55 \times \Delta P_{s} \pm Z l
$$

Where,
$\Delta H l=$ Allowable friction head loss along the lateral, $\mathrm{m}$

$\Delta$ Ps $=$ Allowable head loss in the sprinkler irrigation sub unit, $\mathrm{m}$

$\mathrm{Zl}=$ Elevation difference along the lateral, $\mathrm{m}$

\section{Design of submain}

Selection of submain size depends on frictional head loss in submain. The HazenWilliam equation (equation 3.10) was used to estimate the head loss in the submain.

After checking the suitability of the head loss the size of the submain were finalized.

$l_{s}=1.212 \times 10^{10} \times\left(Q_{s} / C\right)^{1.852}\left(D_{s}\right)^{-4.871} \times L_{s} \times F_{s}$

The flow rate (Qs) of submain is estimated by using equation (3.11)

$Q_{s}=Q_{l} \times N_{l} \quad \ldots$

Where,

$\mathrm{Js}=$ Submain head loss due to friction, $\mathrm{m}$

$\mathrm{Qs}=$ Submain discharge, lph

$\mathrm{Q}_{1}=$ Discharge of individual laterals, $1 \mathrm{ph}$

$\mathrm{N}_{1}=$ Number of laterals on the submain

Ls $=$ Length of submain, $\mathrm{m}$

Ds = Inside diameter of submain pipe, $\mathrm{mm}$

Fs =Reduction coefficient for submain, dimensionless

Maximum permissible head loss along a 
submain is calculated with the equation 3.12.

$\Delta H_{s}=0.45 \times \Delta P_{s} \pm Z_{m}$

Where,

$\Delta \mathrm{Hs}=$ Allowable friction head loss along the submain, $\mathrm{m}$

$\Delta \mathrm{Ps}=$ Allowable head loss in the sub unit, $\mathrm{m}$

$\mathrm{Zm}=$ Elevation difference along the submain, $\mathrm{m}$

\section{Design of main}

The main line carries water from the source to the sub main. Frictional head loss in main line was estimated using equation (3.13).

$l_{m}=1.212 \times 10^{10} \times\left(Q_{m} / C\right)^{1852}\left(D_{m}\right)^{-4871} \times L_{m} \times F_{m}$

The flow rate of mainline $\left(\mathrm{Q}_{\mathrm{m}}\right)$ is estimated using equation (3.14)

$$
\mathrm{Qm}=\mathrm{Qs} \times \mathrm{Ns} \quad \stackrel{\ldots}{(3.14)}
$$

Where,

$\mathrm{J}_{\mathrm{m}}=$ Head loss in main due to friction, $\mathrm{m}$.

$\mathrm{Q}_{\mathrm{m}}=$ Discharge in main line, lph

$\mathrm{Q}_{\mathrm{s}}=$ Discharge in submain, lph

Ns $=$ Number of submains on mainline.

$\mathrm{D}_{\mathrm{m}}=$ Inside diameter of main pipe, $\mathrm{mm}$

$\mathrm{L}_{\mathrm{m}}=$ Length of main, $\mathrm{m}$

Total frictional head loss along a main helped in the size selection which was estimated using equation (3.15).

$\Delta \mathrm{Hm}=\mathrm{Jm} \pm \mathrm{Zm}$

Where,
$\Delta \mathrm{Hm}=$ Total head loss along the main, $\mathrm{m}$

$\mathrm{Jm}=$ Friction head loss in the main, $\mathrm{m}$

$\mathrm{Zm}=$ Elevation difference along the main, $\mathrm{m}$

Size selection of the main line is depend on the two main factors viz., frictional heal loss along the length of pipe and the velocity of the flow through pipe. Therefore the selected size is checked for the permissible velocity of the flow through pipe. The velocity in the main line was estimated using equation (3.16).

Velocity $=\frac{Q_{m}}{A_{m}} \quad \ldots$

Where,

$\mathrm{Am}=$ Cross sectional area of the pipe, $\mathrm{m}^{2}$

The inside diameter of the mainline should be such that the velocity should not exceed the prescribed limit decided on the basis of pipe material to be used. For PVC pipes, generally the maximum permissible velocity must be within $1.5 \mathrm{~m} / \mathrm{sec}$.

\section{Horse power requirement}

Total head of pump sums up the suction head, delivery head, filter losses, mainline loss, operating pressure, fitting loss, Ventury head loss and elevation difference.

The energy requirement to operate the system is estimated using equation (3.17).

$\mathrm{Hp}=\frac{Q m \times H}{75 \times \eta} \quad \ldots$

Where,

$\mathrm{Hp}=$ Pump horse power requirement

$\mathrm{Q}_{\mathrm{m}}=$ Total flow rate in mainline of a field, lps

$\mathrm{H}=$ Total head, $\mathrm{m}$

$\eta=$ Combined efficiency of pump set 
Design of sprinkler irrigation for hypothetical field size

Several combinations of the field sizes were considered in the design tool for the different crop types to make the tool more reliable in terms of the practical adaptability. The algorithms were designed in terms that it will provide the prevailed layout for the particular field size with selected components of the sprinkler irrigation system.

\section{Results and Discussion}

\section{Estimating irrigation requirement of crops}

The procedure for estimation of daily crop water requirement is discussed in section 3.2. The estimation of daily crop water requirement usually requires information of reference evapotranspiration and crop coefficient factor.

\section{Reference crop evaporation}

The daily reference evapotranspiration data of 32 years (1985-2016) calculated using CROPWAT software. The computed average daily reference crop evapotranspiration values on the basis 32 years climatological data are presented in Appendix-A and is observed to vary between $1.97 \mathrm{~mm}$ to $8.45 \mathrm{~mm}$ (Fig. 2).

\section{Crop coefficient}

FAO 56 provided stage wise initial crop coefficient values which are directly adopted in the calculations of daily crop $\mathrm{ET}_{\mathrm{c}}$ and ultimately crop water requirement. The software tool is developed with Microsoft Visual studio 2008 based C programming language.

The adopted language provides an interactive and user friendly interface. Design steps of software tool follow the algorithm which is prepared by following the design actual steps of sprinkler irrigation system. The prepared algorithm follows step by step procedure as explained in the section 3.5.

\section{Crop evapotranspiration}

The daily crop evapotranspiration calculated with the consideration of crop coefficient and reference ET. The detailed procedure is explained in the section 3.2.1.3.

\section{Crop water requirement}

Design of sprinkler irrigation requires crop water requirement. CWR is important factor in design of sprinkler irrigation system. CROPWAT software tool is used for estimating the CWR. CROPWAT is directly linked with the design screen of the developed software.

Basically CROPWAT requires the daily values of meteorological parameters provided the daily crop evapotranspiration. Further daily crop water requirement calculated.

\section{Development of software tool for design of sprinkler irrigation system}

The developed software tool provides optimal design for particular area and crop and also provides tentative quotation. The software is developed in the event driven programming language $\mathrm{C \#}$ and for that purpose the Microsoft Visual Studio 2008 was used.

This programming language provides an interactive and user friendly interface in screens environment. Interactions between the user and the software are supported through a friendly graphical user interface design under integrated development environment of Visual studio 2008. The procedure and methodology followed for the development of the software are described in Section 3.6. 


\section{Software overview}

The software is provided with user-friendly graphical user interfaces which guide user through the complete design process of sprinkler irrigation system to run the model. User just needs to input the necessary data required and demanded by software. Navigation through the model and functionality of software were explained in this section.

\section{Login screen}

Figure 3 gives the idea of Login screen of the designed tool. This screen allows user to put username and password to have start up with the software.

Clear - Clear all the entries entered in the username and password.

Exit- Sprinkler irrigation system design software will be close.

\section{Home screen}

Home screen (Fig. 4) displays names of developers, college name and name of university along with the college logo. Click on button Enter to open main menu screen of software.

\section{Title screen}

The title screen (fig. 5) describes software and the objectives behind the concept. User will come to get overall idea of the software.

\section{Main menu screen}

Main menu screen shows the overview of software i.e. lists of associated screens within the software. The Home, Enter and Exit buttons are provided on this screen. The design process starts with water requirement calculation. User needs to click on the particular link to open the screen for further calculations. The data-update link helps to update the prices of sprinkler irrigation components. This screen goes with following tabs:

Water requirement

Sprinkler selection

Lateral selection

Submain selection

Main selection

Layout

Pump selection

Quotation of design

Benefit cost ratio

Need help

The Enter button is for starting of design, Home button is for home screen and Exit is to shut the screen. Need help button helps new users to get idea about the design considerations.

\section{Water requirement screen}

Calculations regarding water requirement for particular crop comes under this screen (Fig. 7). This screen allows the user to select crop and area of the field. Certain combinations of areas (Length in $\mathrm{m} \times$ Width in $\mathrm{m}$ ) are already provided in the database whereas user can possibly do the design for any other combination as the screen allows to add field size manually. Software tool allows to calculate the crop water requirement in $\mathrm{mm} /$ day. The total crop water requirement is calculated in liter per day for plot. Further, to workout with the area besides database i.e. under Enter area manually tab, user must have the basic knowledge about the design assumptions as well as criteria's too. Next button allows user to jump to the sprinkler screen, whereas, Back button allows receding to previous screen as well as Menu turns to Main menu screen. 
The database of the software includes total of 16 crops viz. onion, pea, cabbage, chilli, cauliflower, brinjal, potato, tomato, wheat, barley, greengram, groundnut, mustard, cotton, sugarcane and sorghum whereas, the field size combinations provided with the database are $50 \mathrm{~m} \times 50 \mathrm{~m}, 100 \mathrm{~m} \times 50 \mathrm{~m}, 75 \mathrm{~m} \times$ $75 \mathrm{~m}, 100 \mathrm{~m} \times 100 \mathrm{~m}, 100 \times 150 \mathrm{~m}, 150 \mathrm{~m} \times$ $150 \mathrm{~m}, 200 \mathrm{~m} \times 150 \mathrm{~m}$ and $200 \mathrm{~m} \times 200 \mathrm{~m}$. The calculated value of total water requirement for the chosen field size displays.

\section{Sprinkler selection screen}

Fig. 8 gives overview of Sprinkler screen. The design specifications are different for different manufacturer so three different companies database were included and displays under the name $\mathrm{A}, \mathrm{B}$ and $\mathrm{C}$ in the selection of the company. User can select any of above company and also company specification and details.

This screen is provide choices for user in terms of sprinkler then nozzle selection and accordingly pressure range which gives wetted area of sprinkler. There are three basic type of sprinklers included in the selection i.e Micro sprinkler, Mini sprinkler and Rain gun along with their nozzle sizes and pressure ratings.

The row to row and plant to plant spacing considered as default input data and Number of sprinkler is calculated by the software. As the sprinkler irrigation generally used for close growing crops, the design is done by 100 per cent overlapping with field dimensions.

Details of the Nozzles for sprinklers are as follows:

Micro sprinkler -black, blue, green, red, white orange and yellow

Mini sprinkler - silver, yellow, purple and orange
Rain gun $-8 \mathrm{~mm}, 10 \mathrm{~mm}, 12 \mathrm{~mm}, 14 \mathrm{~mm}$ and $16 \mathrm{~mm}$ size.

Pressure ratings for different sprinklers are as follows:

Micro sprinkler - $1 \mathrm{~kg} / \mathrm{cm}^{2}, \quad 1.5 \mathrm{~kg} / \mathrm{cm}^{2}$, $2 \mathrm{~kg} / \mathrm{cm}^{2}, 2.5 \mathrm{~kg} / \mathrm{cm}^{2}$ and $3 \mathrm{~kg} / \mathrm{cm}^{2}$

Mini sprinkler $-2 \mathrm{~kg} / \mathrm{cm}^{2}, 2.5 \mathrm{~kg} / \mathrm{cm}^{2}, 3 \mathrm{~kg} / \mathrm{cm}^{2}$, $3.5 \mathrm{~kg} / \mathrm{cm}^{2}$ and $4 \mathrm{~kg} / \mathrm{cm}^{2}$

Rain gun $-2 \mathrm{~kg} / \mathrm{cm}^{2}, 3 \mathrm{~kg} / \mathrm{cm}^{2}, 4 \mathrm{~kg} / \mathrm{cm}^{2}$, $5 \mathrm{~kg} / \mathrm{cm}^{2}$ and $6 \mathrm{~kg} / \mathrm{cm}^{2}$.

When all given parameters were selected the designed software tool provide the values of wetted diameter, total number of sprinklers and total discharge of the plot.

As per selection of company the specifications of nozzle and pressure ratings may vary. After selecting the sprinkler user can close screen by clicking on Exit button or go to the next screen by clicking Next button.

\section{Lateral selection screen}

Lateral screen (Fig. 9 and 10) specifies the detailed design and selection of laterals. The interface of lateral allows the user to enter lateral size. User has to drop down the Select lateral size button and choose appropriate diameter of lateral and then calculated head loss value displays.

The permissible limit of the head loss decided the selection of lateral size. In the software tool, if head loss limit exceed software alarms the user by giving message Invalid Diameter, to choose different combination of size along the length of the submain.

This makes user more easy and fast in the selection of appropriate size of lateral. The screen displays: 
Fig.1 FAO suggested general crop coefficient curve (Allen et al., 1998)

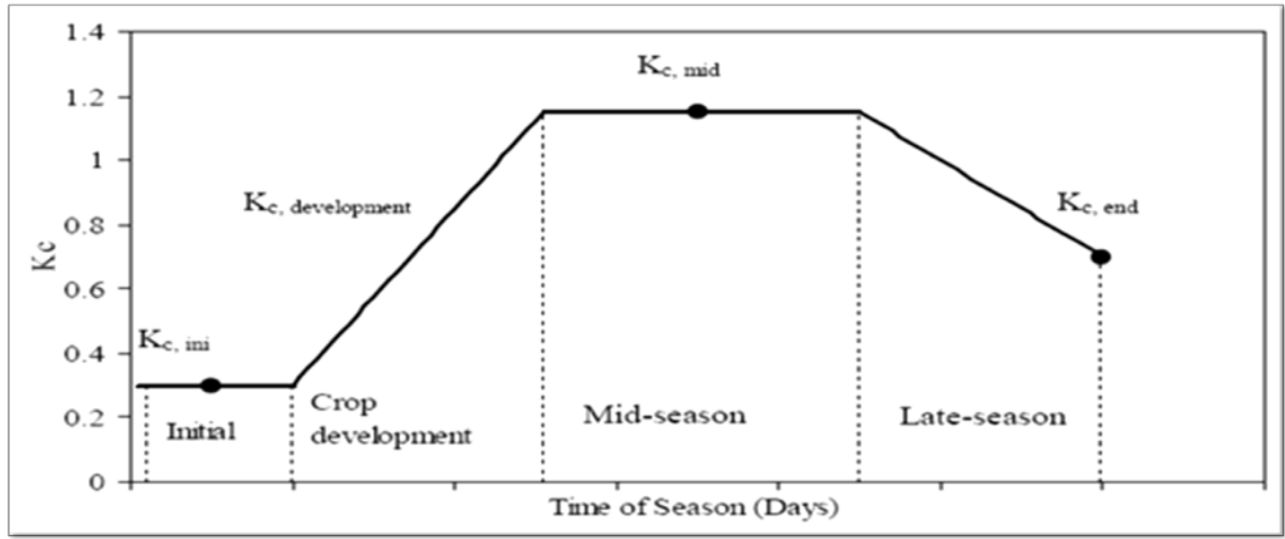

Fig.2 Average daily crop evapotranspiration

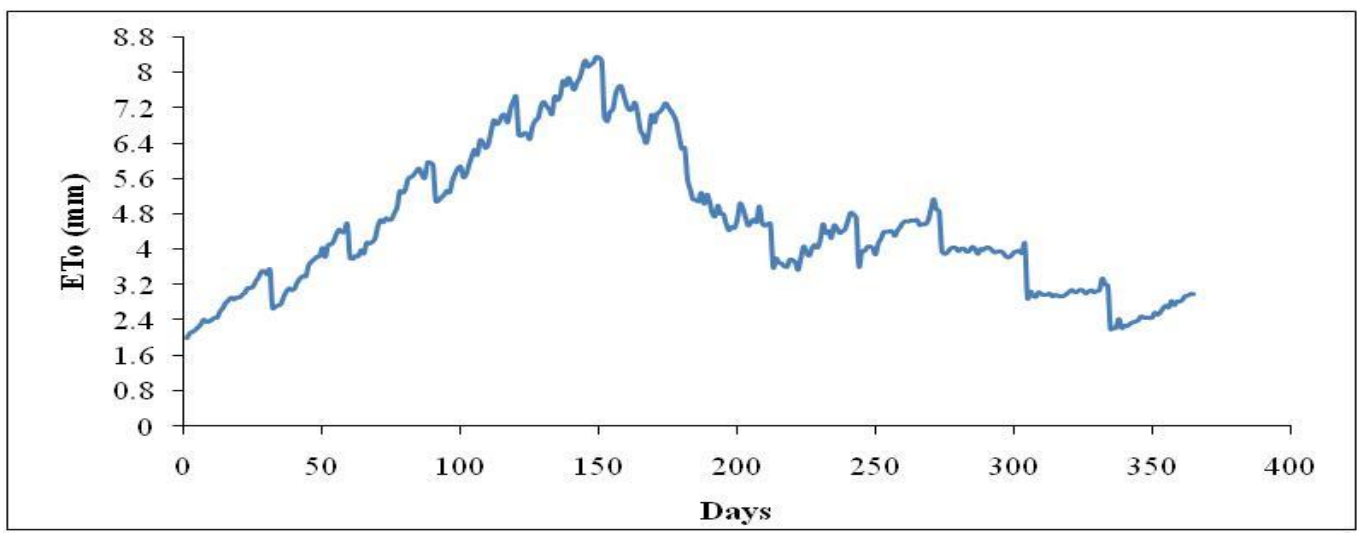

Fig.3 Login screen of software

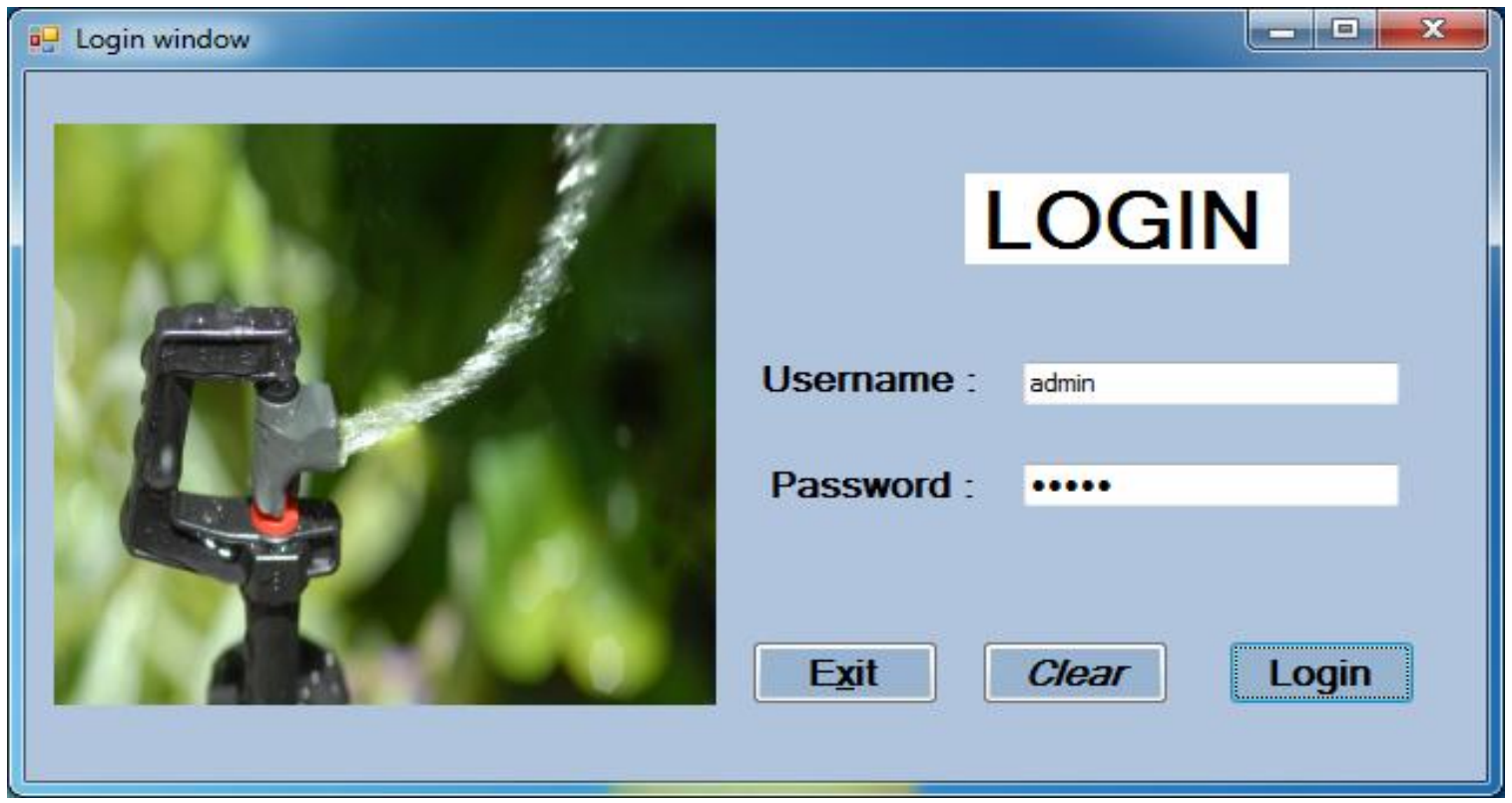


Fig.4 Home screen of software

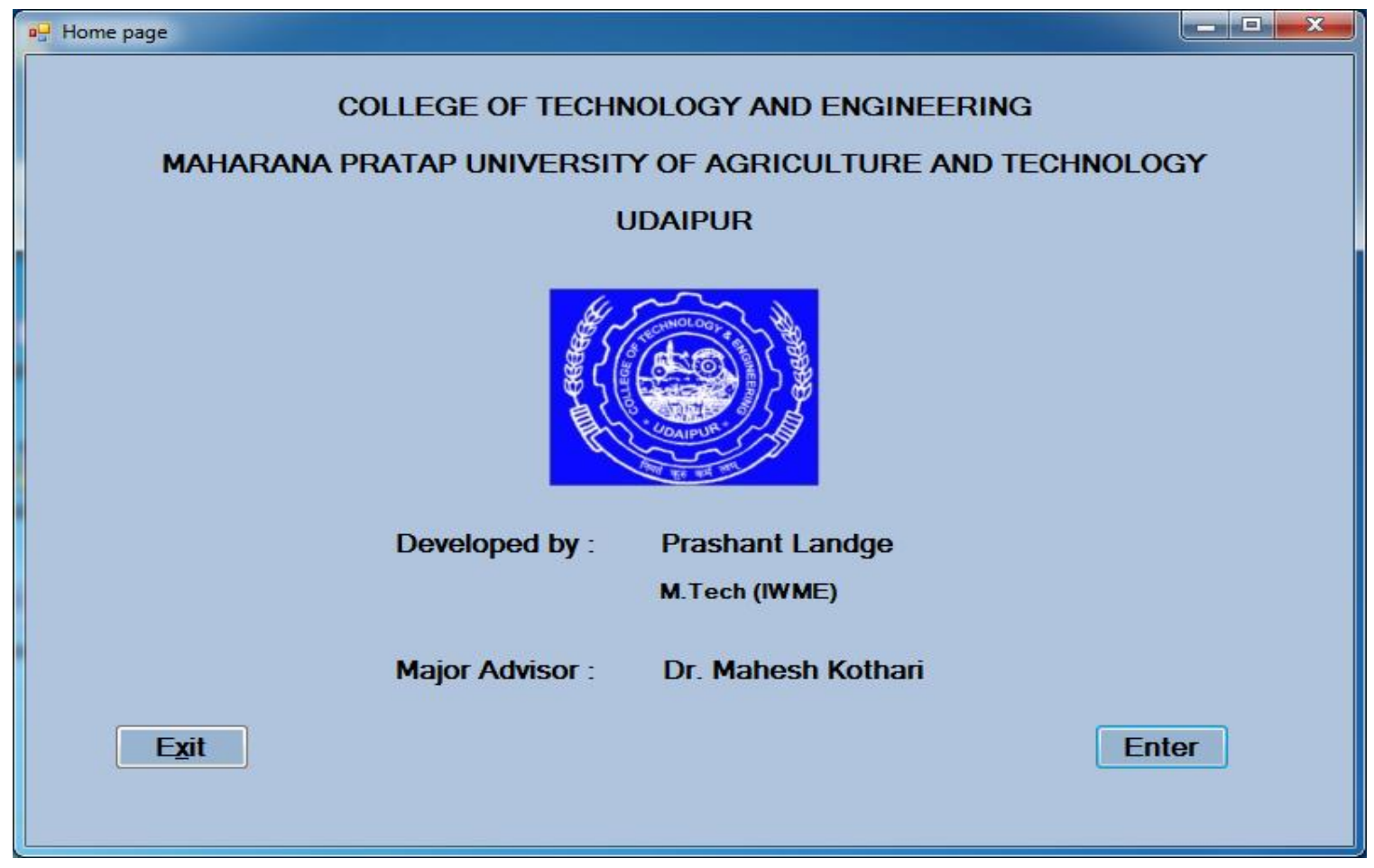

Fig.5 Title screen of software

Project Title

DEVELOPMENT OF SOFTWARE TO DESIGN SPRINKLER IRRIGATION SYSTEM

The software includes design of the area, quotation of the design and benefit cost ratio with respect to crop. The software works on the default area as well as any area given as inputs to it. Software is based on database where the crop water requirment is already given by CROPWAT software which is linked. The inputs are area, selection of crop, and three types of companies which user want to do design. The user friendly software is the need of engineer for giving instant information to the farmer. If the user is not familier with technical specification then HELP command is there for those. Software is less time consuming as well as easy to use with any type of operating system.

\section{Proceed}


Fig.6 Main menu screen of software

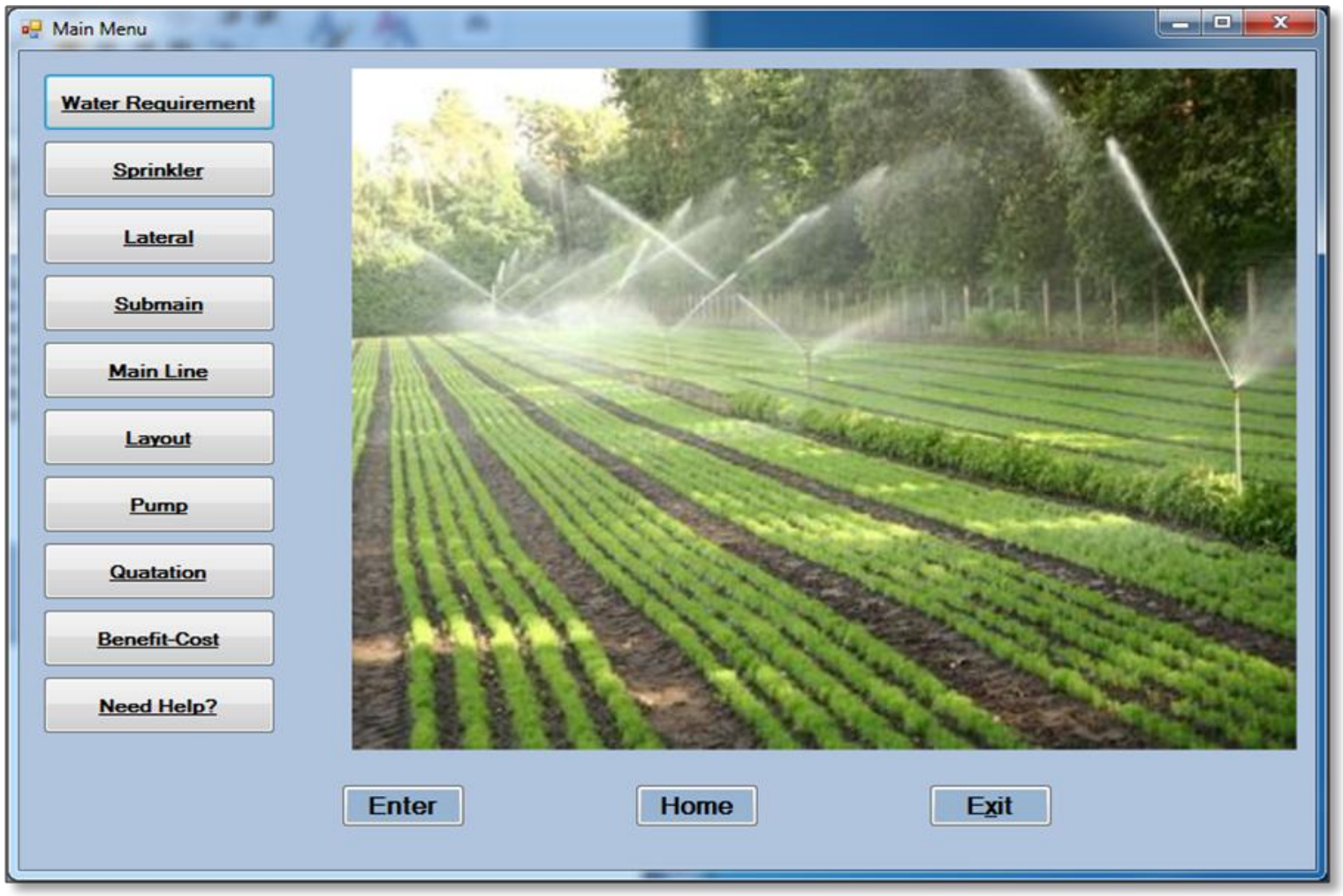

Fig.7 Crop water requirements screen

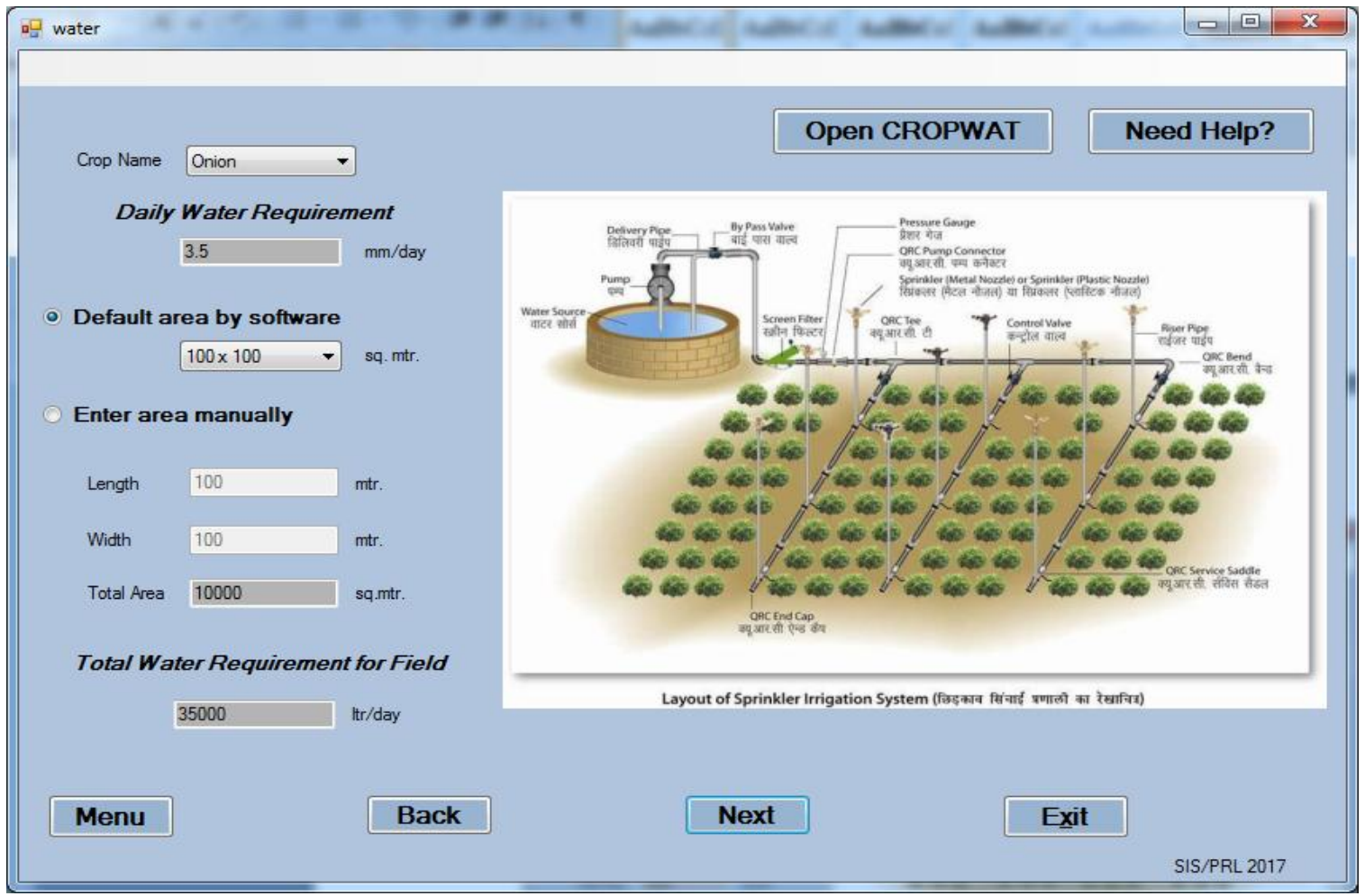


Fig.8 Sprinkler Selection Screen

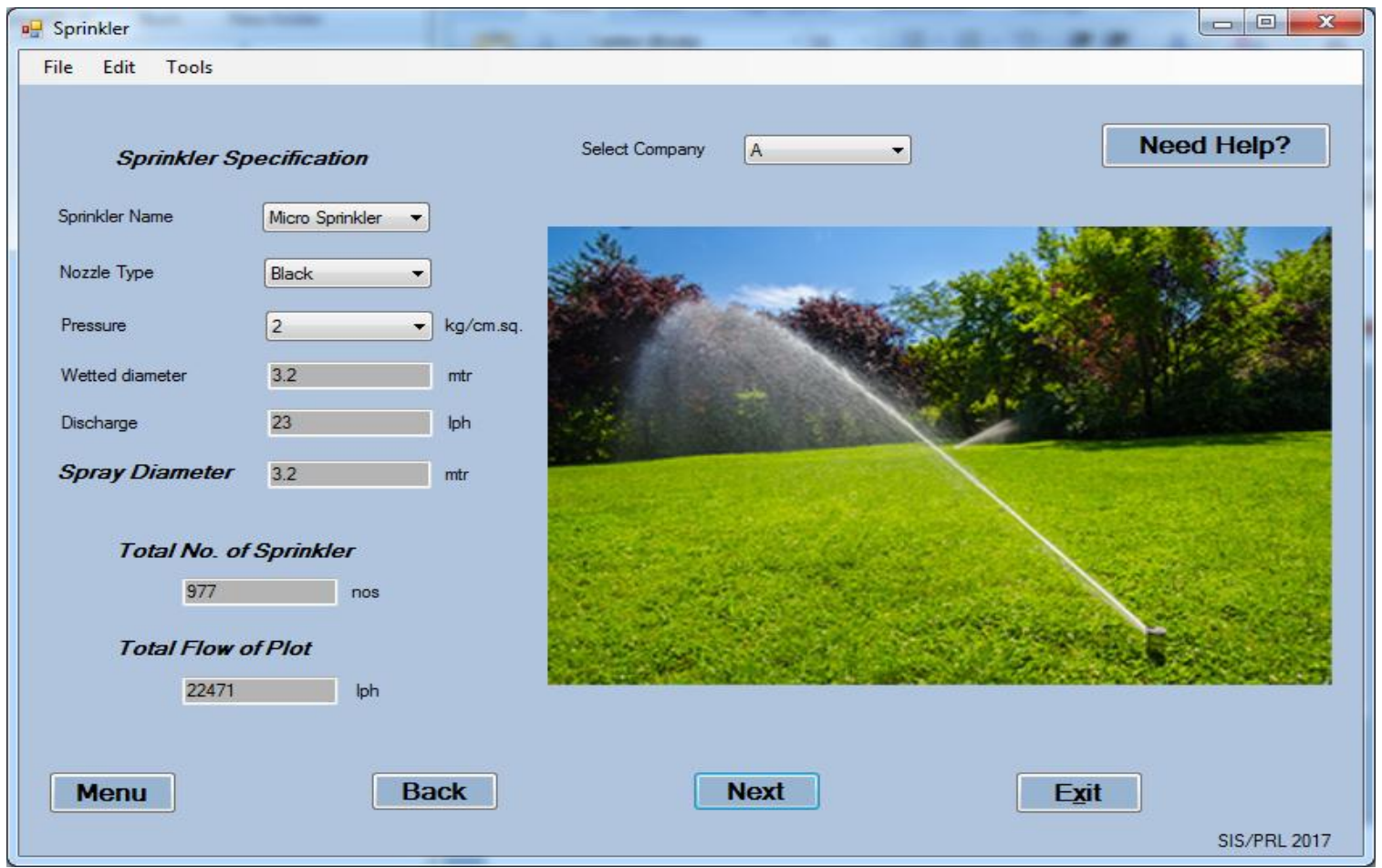

Fig.9 Lateral Selection Screen

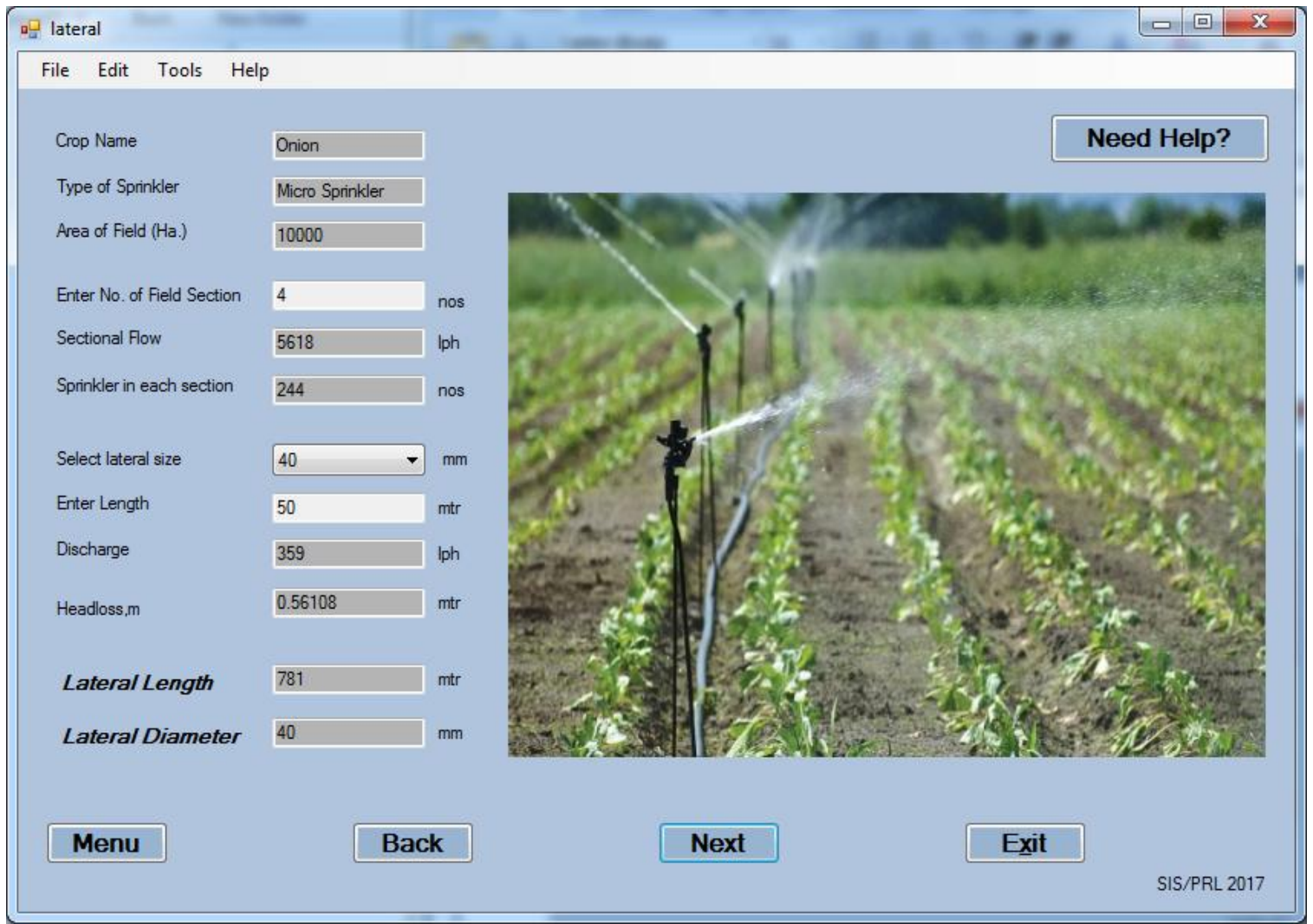


Fig.10 Lateral Selection Screen

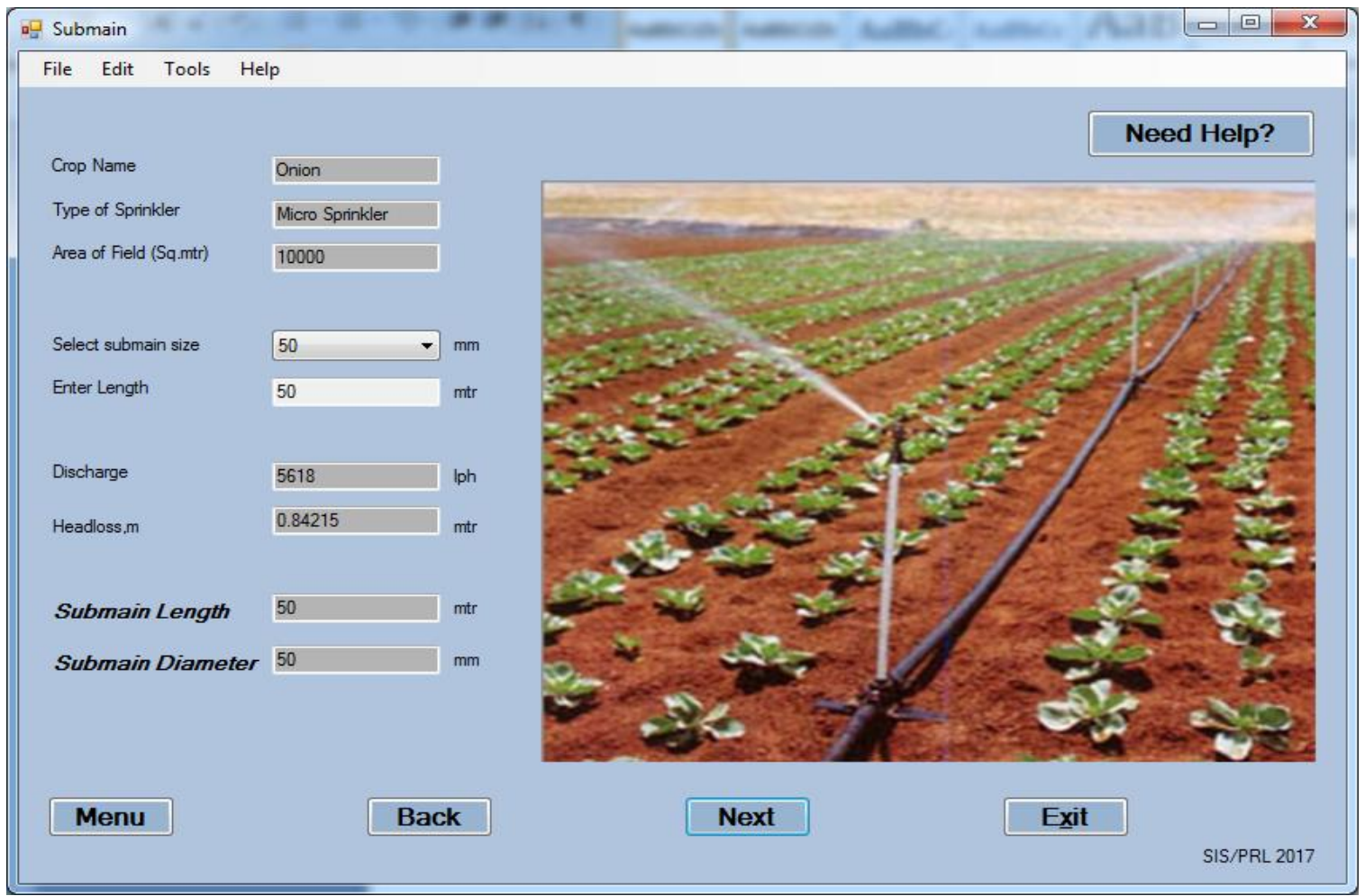

Fig.11 Mainline Selection Screen

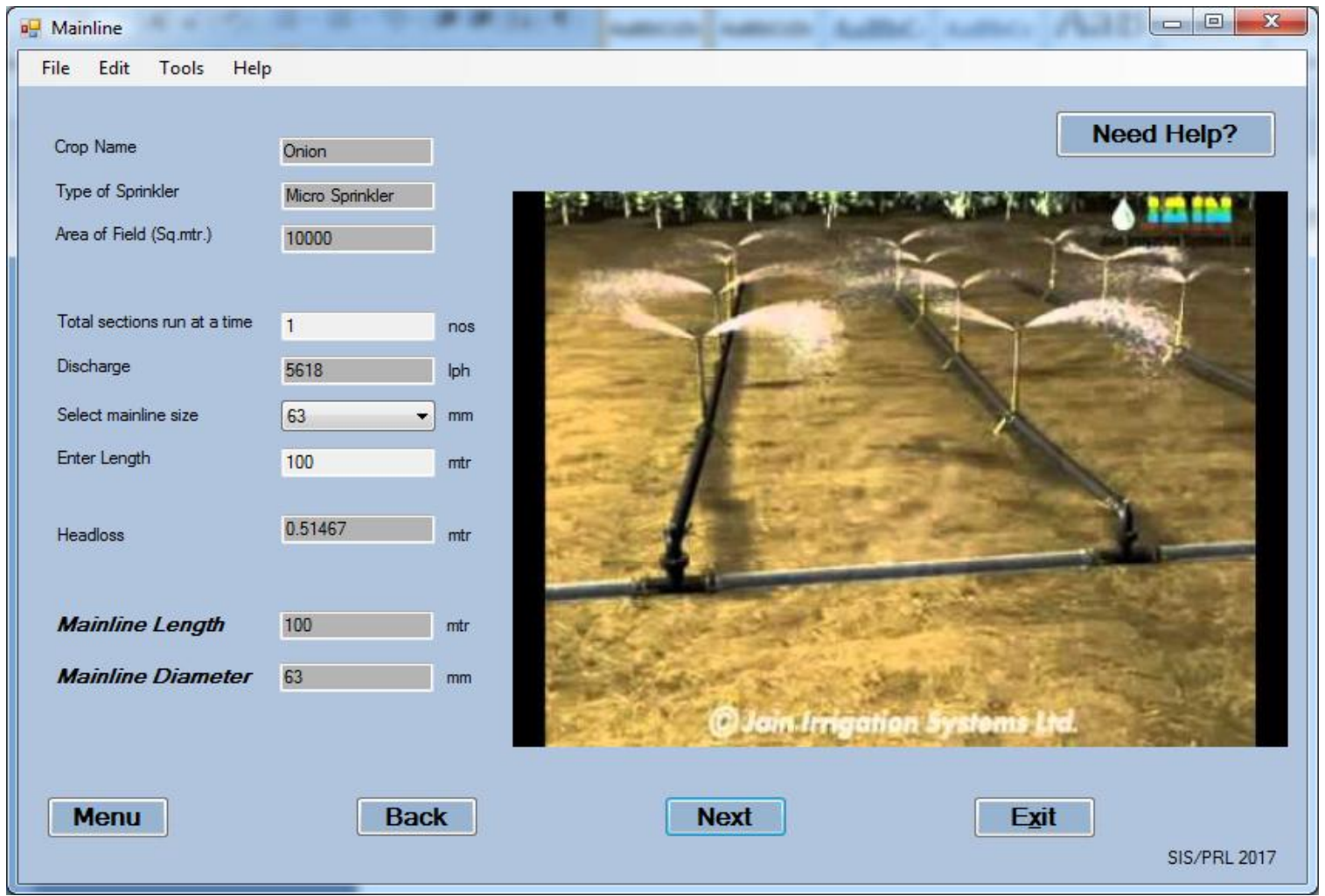


Fig.12 Mainline Selection Screen

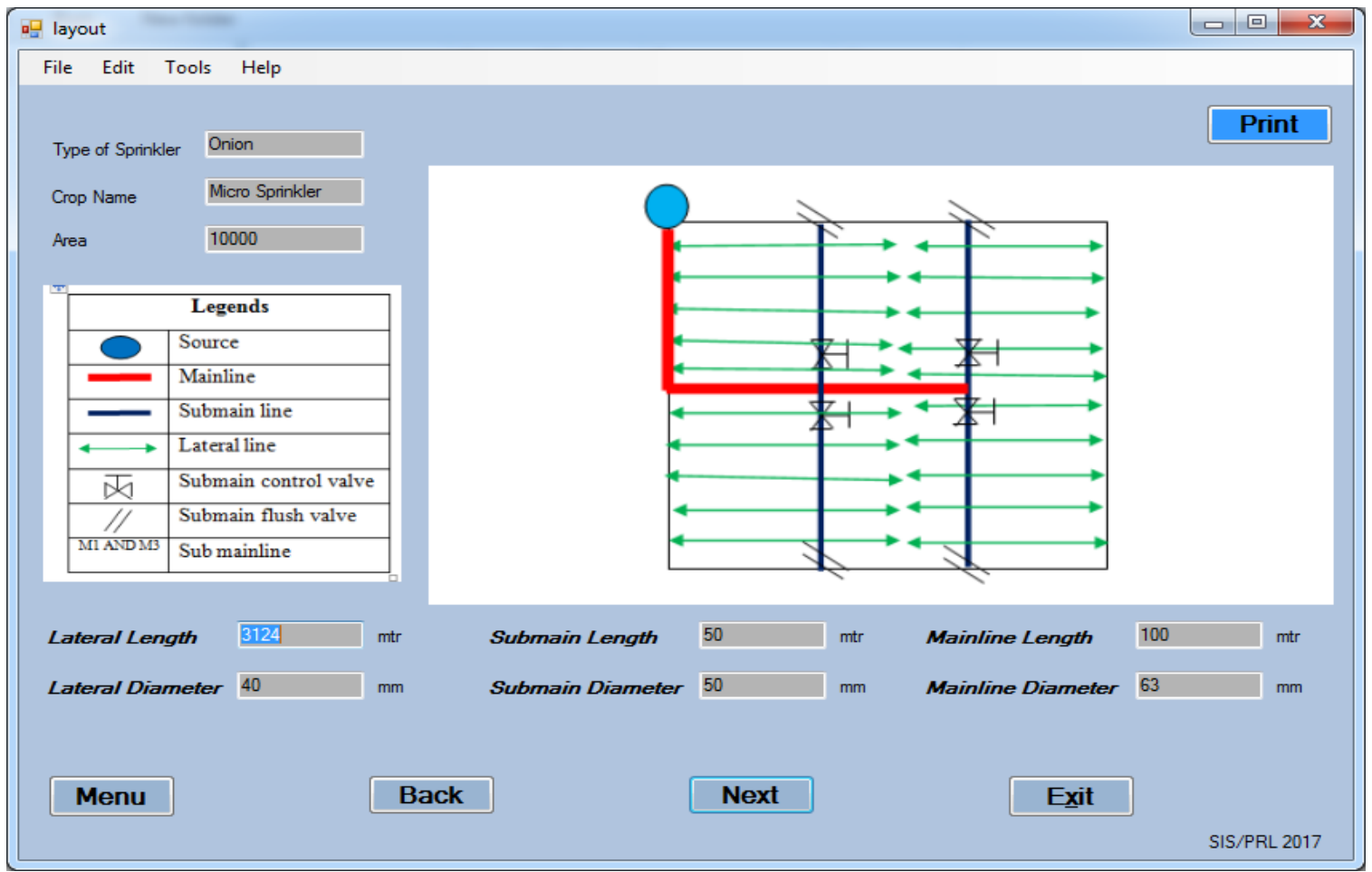

Fig.13 Pump Selection Screen

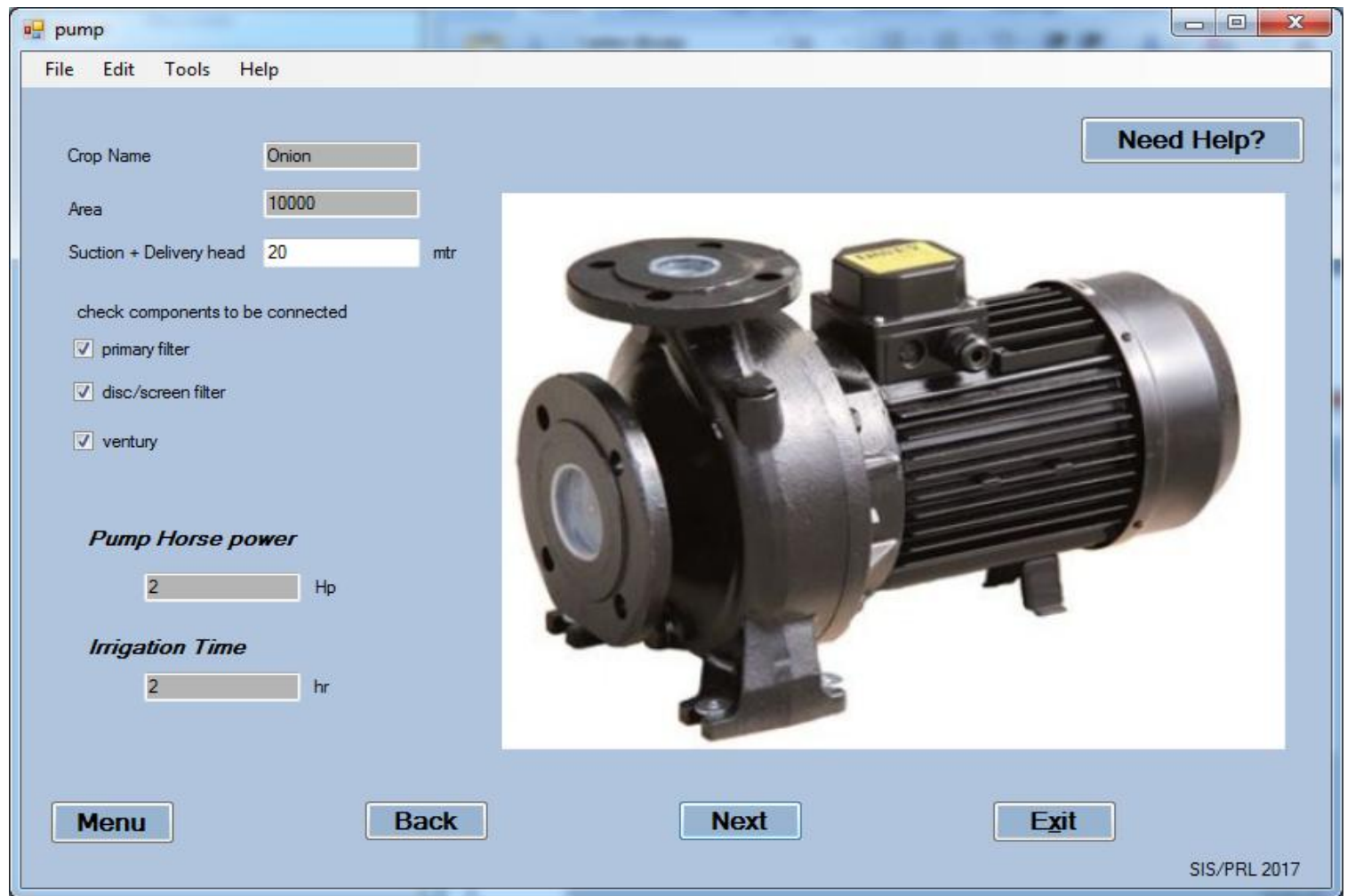


Crop name

Type of selected sprinkler

Area of the field in square meter

No of sections

Sectional flow

Sprinklers in each section

Permissible Head loss, meter

Lateral length of total plot

Lateral diameter

The design of default database is easy to do with software but if design goes with manual operation in software, then user must have the some knowledge of design. Lateral length should not exceed half of the sectional length. After selecting lateral size user may close the screen by clicking the Exit button or go to the next screen by clicking the Next button. Need Help provide guidelines about basic information and working with screen.

\section{Submain selection screen}

The submain screen (Fig. 10) conveys the required quantity of water at desired pressure to all the lateral lines. The selection of submain should be based on economic consideration. Screen consists of following parameters:

Crop name

Type of sprinkler

Area in square meter

Size selection for submain, $\mathrm{mm}$

Discharge, lph

Headloss, meter

Submain length, meter

Submain diameter, $\mathrm{mm}$

User can check the diameter of pipe which is suitable for submain on the basis of head loss. If diameter is not able to carry discharge through pipe as the head loss exceeds limit then result textbox displays Invalid diameter message which alarms user to try certain other combinations. After selecting the submain user can close the screen by clicking Exit button or can go further for design by clicking Next button.

\section{Mainline selection screen}

The sizes of mainline from $40 \mathrm{~mm}$ to $315 \mathrm{~mm}$ are stored in database coding. According to the methodology for mainline design the visual basic loop statements are developed for performing the iteration of design steps. The versatility of $\mathrm{C \#}$ loop statements lies in its ability to perform set of instruction repeatedly. Hence this software is programmed using loop statements which repeat a design step of mainline until the headloss of mainline criteria is being satisfied. The proposed mainline (Fig. 11) screen shows following details:

Crop name

Type of sprinkler

Area in square meter

Total sections run at a time

Select mainline diameter, meter

Enter length, meter

Headloss, meter

Mainline length, meter

Mainline diameter, $\mathrm{mm}$

After selecting proper mainline diameter user can close screen by clicking on Exit button or move forward for design by Next button.

\section{Layout screen}

The layout screen (Fig. 12) provides output of all the technical parameters as follows,

Type of sprinkler

Crop name

Area in square meter

Design of field

Lateral diameter, $\mathrm{mm}$

Lateral length, meter

Submain diameter, $\mathrm{mm}$

Submain length, meter

Mainline diameter, $\mathrm{mm}$

Mainline length, meter

The layout and design details can be printed using Print button. Exit button closes the screen and user can move to further screen under Next button. 


\section{Pump selection}

The pump screen (Fig. 13) goes with selection of pump. User need to enter the values for suction and delivery head and also had a choice to choose the filters and fertigation units so the head values of the accessories will be added in the total head as per the user's design demand. Selection of filters and ventury (fertigation unit) connected to the system adds the head loss accordingly. If user does not required the filter or ventury in the sprinkler irrigation system then user can unmark that component on the particular checkbox. The calculated horse power displays in Pump Horse Power box whereas, the irrigation time in hrs also displays in Irrigation Time box.

Based on all the objectives and executing of the methodology the software tool is developed for design of sprinkler irrigation system. On the basis of practical applicability the following conclusions are derived from the study and are: Software tool found user friendly when trialed with the field expert and farmers due to technical specifications provided in each screen of the software.

Software tool successfully provides the details of selection of lateral size, submain size, mainline size, design of pump and tentative quotation for the particular design.

Software tool also provide the design parameter and layout for hypothetical field areas. Layout provides the details of lateral diameter, lateral length, submain diameter, submain length, mainline diameter and mainline length according to field area by calculating the permissible head loss.

Designed software tool able to provide tentative quotation for the designed sprinkler irrigation system in terms of the quantity of accessories required and the cost of the accessories. In the calculation of economics user allowed to enter the values of variable costs manually this makes software more reliable.
The software reduces the time for design and quotation for the survey.

\section{References}

Adeniran, K. A, F. A. Adeniji, M. F. Amodu and M.O. Amodu. 2010. Water requirements of some selected crops in Kampe dam irrigation project. AJAE 1(4):119-125 (2010).

Gadge, S.B. 2010. A model for adoption of micro irrigation methods in a canal command area. An unpublished Ph.D. thesis submitted to Maharana Pratap University of Agriculture and Technology, Udaipur, Rajasthan.

Goncalves, J. M., M. G. Horst, L. S. Pereira, J. Rolim and A. Muga, 2007. SADREG, a DSS for Improving Surface Irrigation Systems EFITA/WCCA 2005 25-28 July 2005, Vila Real, Portugal.

Hanafy, M., A.M. El-Berry, A.R. Abu-Habsa and B.L. Bishara, 2006.A simple model for designing micro irrigation lateral with the microtube as an emission point. Misr Journal of Agricultural Engineering, 23(1): 96-107

Harmanto, A. 2005. Water requirement of drip irrigated tomatoes grown in greenhouse in tropical environment. Agricultural Water Management 71: 225-242.

Himanshu, S.K., Kumar S., Kumar D. and Mokhtar A. 2012.Effects of Lateral Spacing and Irrigation Scheduling on Drip Irrigated Cabbage (Brassica oleracea) in a SemiArid Region of India. Research Journal of Engineering Sciences, 1 (5):1-6.

Holzapfel, E.A. and A. Pannunzio. 2009. Design and management of irrigation systems. Chilean Journal of Agriculture Research 69(Suppl.1), pp 17-25.

Jensen, M.E. 1969. Scheduling Irrigations with Computers. Journal of Soil and Water Conservation 29(5): 193-195.

Jensen, M.E., D.C.N. Robb and C.E. Franzoy. 1970. Scheduling Irrigations Using Climate-Crop-Soil Data. Journal of the Irrigation and Drainage Division 96(1): 2538. 
Kang, Y. 2000. Effect of operating pressure on micro irrigation uniformity. Journal of Irrigation Science 20:(1) 23-27.

Kang, Y. 2000.Hydraulic Characteristics and Computerized Design of Microirrigation Systems. Ecosystem Service and Sustainable Watershed Management in North China International Conference, Beijing, P.R. China, August 23 - 25, pp. 475-493.

Lakhadar, Z., A. Kettab and G. Chasseriaux. 2006. Design of a micro-irrigation system based on the control volume method. Biotechnol. Agron. Soc. Environ. 2006 10(3), $163-171$.

Mahrous, A., M. Hanafy, G.A. Bakeer and A.S. Bazaraa. 2008. Computer program for predicting emission uniformity of oddshaped subunits in drip irrigation system. Misr J. Agril. Engg., 25(4): 1240-1255

Mane, M.S., Ayare, B.L., Magar, S.S. 2008. Principles of Drip Irrigation System, Jain Brothers, New Delhi, pp 24 - 87.

Manjunatha, M.V., Shukla, K.N., Chauhan, H.S., Singh, P.K. and Singh, R. 2001. Economic Feasibility of Micro Irrigation System for Various Vegetables. In: Proceeding of International Conference on Micro and Sprinkler Irrigation System held at Jalgaon, Maharashtra during 8-10 February, 2000, Jain Irrigation Hills, India. Singh H.P, Kaushish S.P., Kumar A., Murthy T.S. and Samuel J. C. (Eds.) Micro irrigation, pp 359-364

Michael, A.M. 2010. Irrigation: Theory and Practice. Second Edition, Vikas Publishing House Pvt. Ltd. New Delhi, India.

Mostafa, E.A. 2004.Correction factor for friction head loss through lateral and manifold. Eighth International Water Technology Conference, IWTC8 2004, Alexandria, Egypt.
Patil, P.B., M.U., Kale, S.B. Wadatkar, and G.S.Pawar. 2014. Irrigation scheduling using computer software. Internat. J. Agric. Engg., 7 (1): 42-45.

Patil, R.V., Bhosale, A.B. and Takte, R.L. 2010.Effect of drip irrigation and fertigation levels on growth and yield of gerbera under greenhouse conditions. Ecology, Environment and Conservation, 16 (2): 235-237.

Pedras, C.M.G. and L.S. Pereira. 2009. Multicriteria analyses for design of microirrigation systems: Application and sensitivity analyses. Agriculture water management 96, pp. 702-710.

Pedras, C.M.G., L.S. Pereira and J.M. Goncalves. 2009. MIRRIG: A decision support system for design and evaluation of microirrigation systems. Agriculture water management 96, pp. 691-701.

Rajan, N. and J.M. Stephan. 2006. Estimating daily and seasonal crop water use of high plains cropping systems using remote sensing and crop modelling. Southern Conservation Systems Conference, Amarillo TX, June, 2006: 25-30.

Rao, B.K. and T. B. S. Rajput 2009.Decision support system for efficient water management in canal command areas.Current Science, vol. 97, NO.1, 10.

Satpute, S. T., Singh, M., Parihar, S. S., Khanna, M., Singh, D. K. and Joshi, S. 2008. Response of garlic to different crop geometry under micro irrigation regimes.Journal of Water Management, 16 (1): 22-27.

Shahabi, S.O. and M. Vazifedoust 2011. Development of Software for Automatic Designing of Pressurized Irrigation Systems. $21^{\text {st }}$ International congress on Irrigation and Drainage of ICID 16-22, Tehran, Iran. Research paper: 28, pp243.

\section{How to cite this article:}

Landge, P.R., M. Kothari, S.R. Bhakar, P.R. Patil and Patil, M.A. 2018. Design and Evaluation of Software Tool for Optimal Design of Sprinkler Irrigation System. Int.J.Curr.Microbiol.App.Sci. 7(02): 2660-2677. doi: https://doi.org/10.20546/ijcmas.2018.702.323 